\title{
Organizational Communication Study: Organizational Control Theory Implementation by HMI Purwokerto Branch in the Omnibus Law Demonstration
}

\author{
Pundra Rengga Andhita*1, Ade Tuti Turistiati ${ }^{1}$, \\ Muhammad Jamiluddin Nur ${ }^{2}$ \\ ${ }^{1}$ Communication Studies Program, Amikom Purwokerto \\ University, Purwokerto, Indonesia \\ ${ }^{2}$ Communication Studies Program, Mataram University, Nusa \\ Tenggara Barat, Indonesia
}

Article Information

Submitted April 21, 2021

Revised July 03, 2021

Accepted August 30, 2021

Published October 01, 2021

\begin{abstract}
This study aims to examine the organizational communication control strategy carried out by the Purwokerto Branch of the Islamic Student Association (HMI) to demonstrate the Ratification of the Job Creation Bill (Omnibus Law). The method used is descriptive qualitative using organizational control theory as a theoretical framework. The results showed that the involvement of the Purwokerto Branch of HMI in the Omnibus Law demonstration was a critical intellectual movement that arranged forward a constitutional approach. The simple control aspect is implemented through a three-layer communication mechanism. The solidarity of members towards the three layers of communication constructs communication conduct harmoniously. HMI uses two technical tools for technical control, specifically communication aids and internal identification tools as non-verbal symbols of the organization. There are strict controls to identify members in the demonstration through the symbol. Regarding bureaucracy, this organization prioritizes communication with local authorities regarding the fulfillment of formal rules before holding a demonstration. In addition, organizational procedures are also carefully considered, especially regarding consolidating the organization's internal communications. Conservative control is implemented by strengthening interpersonal communication with active members or alumni networks spread across various professions. The organizational communication control strategy of the HMI Purwokerto Branch focuses on the harmonization of demonstrations that prioritize aspirational and implementation communication by emphasizing a constitutional approach.
\end{abstract}

Keywords: Demonstration, HMI, Omnibus Law, Organizational Communication, Organization Control

\section{Introduction}

The ratification of the Employment Creation Bill (Omnibus Law) into the Job Creation Law at the DPR plenary meeting on October 5, 2020, was controversial. Of the nine factions in the DPR, seven factions approve the law's ratification, specifically, PDIP, Golkar, Nasdem, Gerindra, PKB, PPP, and PAN. Meanwhile, the other two factions, the Democrats and the PKS, voted against it. The process of enacting this law is entire of controversy. Rejections from the public have been noticed since this law was proposed. The process to construct the law was considered closed. In addition, there are also other substantial reasons, such as the potential for

\footnotetext{
*Author Correspondence: Pundra Rengga Andhita, email: pundra@amikompurwokerto.ac.id, Program Studi Ilmu Komunikasi, Universitas Amikom Purwokerto. Jl. Letjend Pol. Soemarto No.126, Watumas, Purwanegara, Kec. Purwokerto Utara, Kabupaten Banyumas, Jawa Tengah 53127.
}

Copyright (C) 2021 Pundra Rengga Andhita, Ade Tuti Turistiati, Muhammad Jamiluddin Nur 
environmental damage and the increasingly diminishing workers' rights (Prabowo, 2020).

Public opinion regarding the job creation bill process is in line with Munadhil Abdul Muqsith's opinion, which stated that the mechanism of this bill was only discussed in 64 meetings from April 20 to October 3, 2020. The process is considered very fast, not participatory, and lacks transparency. The legislative process is considered negligent in presenting a democratic (Muqsith, 2020). Apart from a lack of transparency assumption and public participation, several points in this law are also considered not according to the community's interests. Some of these points relate to abolishing the minimum wage, overtime hours, rest periods, work contracts, and foreign workers' recruitment. Furthermore, the ratification of this law triggered demonstrations from many elements of society. One of them is a student organization.

According to Law no. 9 of 1998 article 1 paragraph 9, demonstrations are activities carried out by one or more people to express thoughts verbally, in writing, and an emotional expression in public. In Indonesia, according to the mandate of the 1945 Constitution article 28, demonstrations can be considered the right of citizens to associate and assemble, express thoughts, and verbally as regulated by law. As long as the demonstration does not contradict existing regulations, this activity can be comprehended as a constitutional right, the implementation of freedom of responsibility for every citizen in responding to government policies related to the public.

In response to the ratification of the Omnibus Law, some elements of society involved in the demonstration were quite diverse, ranging from workers, community groups, workers' groups, community organizations to student organizations. Protests also took place in several areas. One of them occurred in Purwokerto, Banyumas Regency, Central Java. In Purwokerto, a demonstration against the Omnibus Law was held by several people consisting of community organizations and students.

The protest against the Omnibus Law Law in Purwokerto on Thursday, October 15, 2020, was chaotic. Since noon, some masses gathered and gave speeches around 14.00 WIB in Purwokerto square, the landmark area of the Banyumas Regency Regent. Until the evening, the crowd persisted in that location. Although the police had urged the masses to disperse, the masses refused, awaiting the fulfillment of their demands with the regent of Banyumas, Ir. Ahmad Hussein (Anugrah, 2020). The masses wanted the Banyumas regent to give their support, signing the rejection of the Omnibus Law. Although the regent was initially reluctant to meet the masses, the regent finally agreed after some time. It is just that the response is not as desired by the masses. Ir. Ahmad Husein was greeted by the screams of disappointed students.

"Concerning all of my children, I sincerely apologize profusely. I did not fulfill, and I could not fulfill all of my children's requests. Unless I am ready to take my children's aspirations to the top."

The regent's statement was considered disappointing by the masses. This statement triggered the masses to act aggressively and negotiate with the regent to change his decision. The police handled the chaotic situation by warning the crowd to disperse. However, the crowd still refused, the police finally fired water cannons and tear gas. The masses were seen running and away from 
the regent's office area. As a result, several students from the masses were injured. The demonstration chaos in Purwokerto indicates the involvement of parties driving students' interests. "The police chief also revealed that when students staged demonstrations, they could tighten up the provocateurs for other purposes. The police consider that the joint action of students and many mass organizations (Kompas), there are indications that it was ridden" (Suara Muhammadiyah, 2020). This indication was reinforced by the Minister of Defense of the Republic of Indonesia's statement, Prabowo Subianto. According to him, the riots during demonstrations against the law were driven by foreigners. Prabowo Subianto believes that the people cannot destroy the facilities built with the people's capital (Prabowo, 2020).

Demonstrations are one method to achieve social change through sustainable collective action (Selvanathan \& Lickel, 2018). Collective action through demonstrations is essential in a democratic climate. Although sometimes provocation has a harmful intent, precise movements that aim to spur the opponent to do actions detrimental to themself are destructive and can have severe consequences for the object of provocation (Tumskiy, 2019). However, public participation through provocation movements needs to be understood as a positive response, as a form of direct supervision of policies taken by the government.

Chaos in demonstrations is not natural, but intruders from outside the participants. Riots can be avoided if the participants can control good organizational communication among their members. One of the demonstration participants who could control his members was the Purwokerto Branch of
HMI. None of the HMI Purwokerto Branch members were injured or secured by the police for alleged law violations. This picture shows a harmonious organizational communication control within the HMI Purwokerto Branch. This organization focuses on the goal of the action, explicitly achieving support from the regent and the chairman of the regional representative council to reject the Omnibus Law. Organizations need to focus on one predetermined goal. The communicative coordination process is essential to achieve the action goal (Schoeneborn, 2011).

General Chairperson of the HMI Purwokerto Branch, Giovani Helmi Munif, stated:

"In the demonstration against the Omnibus Law, we have prepared thoroughly. We control members to comply with existing demonstration mechanisms. Do not violate the provisions and focus on the goal" (Munif, interview, January 25, 2021).

Reasonable organizational communication control can minimize the potential for goal bias by the organization. HMI is the oldest student organization in Indonesia and has taken many contributive, innovative, and positive roles in the history of Indonesia. Since its establishment on February 5, 1947, HMI has always played a strategic role in challenging the ummah (Islamic community) and this nation (Wekke \& Mukhtar, 2007). This illustration shows that HMI's demonstration journey has matured and is professional. Likewise, in the Omnibus Law demonstration, the participation of the Purwokerto Branch of HMI cannot be separated from the awareness to carry out the function of social criticism for the government related to community problems. The masses of Omnibus Law demonstration are very heterogeneous, gathered in one area from 
various backgrounds. However, this crowded situation did not drive this organization to lose control. Focus on goals and the common good.

Good organizational control also depends on the mechanism of organizational leaders in communicating goals, vision, and mission to its members. Administrative control is a mechanism used by organizational leaders to direct attention and motivate members to act as organizational goals. (Cardinal, 2001; Eisenhardt, 1985; Govindarajan and Gupta, 1985; Jaeger and Baliga, 1985; Kerr, 1985; Langfield-Smith, 1997; Ouchi, 1977, 1979; Snell, 1992). Organizational control is one of the topics in organizational communication. According to Cardinal et al. (2004), organizational control is related to how an organization can exert influence to achieve its goals (Liu, Borman, \& Gao, 2013). Control in the organization is carried out in four ways. 1) simple control, such as using orders or using power sincerely; 2) technical control is a control to set limits on the tools used by organizational members; 3)bureaucratic control, organizational procedures, and formal rules; 4) conservative control, the use of interpersonal relationships and teamwork to understand the reality and values of the organization (Novianti, 2019).

Organizational control theory focuses on the organization's internal control, paying attention to how members of the organization can follow the directions, rules, or instructions of the organization's leader. In this case, the organization's leadership will communicate the control through written or unwritten rules that have been agreed upon in advance. Applying rules from the organization's leadership is the core of organizational control. In line with Chomsky (1968), which states that control in organizations is achieved through rules. These rules do not have to be formally defined by organizational members, although they may be. They do not depend on the consciousness of their members for their analytical utility-rules as terms that can define the particular structure that underlies organizational life (Clegg, 1981). Furthermore, organizational leaders who can communicate organizational control sufficiently will encourage their members to act and behave according to the goals that have been set. Based on this reason, this research wants to examine the organizational communication control strategy carried out by the Purwokerto Branch of HMI in action against the Omnibus Law in Purwokerto.

\section{Method}

This study used the descriptive qualitative method. The population in this study were HMI Purwokerto Branch members who were involved in the Omnibus Law demonstration on October 15, 2020, in Purwokerto, Banyumas Regency, Central Java. The sampling results were used as a source of interview data in this study. Data sources consist of primary and secondary data.

Primary data were acquired through indepth interviews and observation. Interviews were conducted by selecting relevant criteria from the existing population. Stokes (2006) stated that the determination of the number of resource persons was taken based on the criteria for eligibility and competence in indepth interviews. In line with Bernard's (1998) theory that the determination of sources is not based on representation (Syahputra, 2017). The criteria are the Purwokerto Branch HMI members who structurally play a central 
role in controlling the organization during the demonstration against the Omnibus Law, precisely, the Head of the Purwokerto HMI Branch, and the Field Coordinator for the Omnibus Law demonstration in Purwokerto. Observations were made by directly observing the demonstration against the Omnibus Law in Purwokerto. The secondary data in this research is literacy studies. For data analysis, this study uses an interactive data analysis model by Miles and Huberman through three stages, specifically data reduction, data presentation, and conclusion drawing. While data validation is done by applying triangulation of data techniques which is done by checking the same data source with different techniques.

\section{Result and Discussion}

In a demonstration against the Omnibus Law Law on October 15, 2020, in the area of the regent- the regional representative council office, Purwokerto square, Banyumas Regency, HMI Purwokerto Branch deployed approximately 100 members, male and female. All members arrive from various commissariats within the administrative area of the HMI Purwokerto Branch. The general Chairman led the demonstration directly, assisted by one Field Coordinator and three Assistant Field Coordinators. The field coordinator and the assistant field coordinator are determined by looking at their competence, intellectual maturity, emotional and qualified experience.

In the demonstration, the Purwokerto Branch of HMI joined the Alliance of Mobilizing Society Unions (SEMARAK) and approximately 33 other organizations, which were student organizations (internal and external campuses) and community organizations. Eight demands were communicated, specifically, (1) a distrustful motion against the government and the DPR RI. (2) DPR RI should revoke the ratification of the Omnibus Law on Job Creation. (3) President of the Republic of Indonesia should issue a Government Regulation instead of Law (PERPPU) to replace the Omnibus Law on Job Creation. (4) The regional representative council participate in rejecting the Omnibus Law on Job Creation. (5) Urge the central government to resolve the problem of the Covid-19 pandemic immediately. (6) Realize true agrarian reform and build national industrialization. (7) DPR RI should involve the community in forming future regulations. (8) DPR RI should rationalize policies during the Covid-19 pandemic.

Head of HMI Purwokerto Branch, Giovani Helmi Munif said,

"The narrative description that we have raised focuses on these demands. We do not want other narratives to ride on these demands" (Munif, interview, January 25, 2021).

Munif emphasized this message to his members in demonstrating against the Omnibus Law in Purwokerto. In a demonstration situation followed by a heterogeneous mass, organizational leaders must communicate factual, clear, unanimous, and complete narratives with their members. A unanimous narrative is determined through members' internal communication by conducting in-depth discussions about the factuality and actuality of the Omnibus Law. This narrative is important because, in the era of post-truth politics, various facts emerge, and it becomes a significant challenge for the public to determine which facts will be ignored and included in the policy process 
(Boossabong \& Chamchong, 2020).

Related to the target in this action is the support from the Regent of Banyumas, Ir. Achmad Husein, and The chairman of the regional representative council, dr. Budhi Setiawan was implemented by signing the text of the demands. Furthermore, the signed demands draft is planned to be escorted by the Purwokerto Branch of HMI and other organizations to be brought to the DPR RI's main level. At this point, the role of organizations is crucial in the relationship between government and society, not only on a national scale but also globally. Organizations play an important role in contemporary societies worldwide (Schäfer \& Fähnrich, 2020).

Unfortunately, the demonstration lasted almost nine hours did not reach the protesters' results. The Regent of Banyumas refused to sign the text of the demands from the enthusiastic participants. This refusal prompted the masses to carry out further negotiations, but the police thought that the demonstration had exceeded the stipulated time limit. The police warned the masses to disperse. However, the atmosphere suddenly evolved tense and chaotic, punctuated by tear gas and water cannons. There is a mass group that becomes aggressive. Regarding this incident, the Chairperson of the HMI Purwokerto Branch ensured that no HMI members were involved in destroying public facilities and using swear words at the police.

"HMI members do not carry weapons and do not equip themselves with stones or anything else. Our organization's internal communications are upright. That is a clear rule, and we have agreed. We do not want chaos" (Munif, interview, January 25, 2021).
Prior to the action, the HMI Purwokerto Branch had conducted an in-depth internal study and built solid communication within the organization. Several rules have been mutually agreed upon and have been thoroughly communicated to all its members. Munif ensured that the internal communication of the HMI Purwokerto Branch was dynamic but still harmonious. At this point, communication plays a central role in applying rules in the organization. Johlke and Duhan (2000) explain that communication in an organization also plays an essential role in conveying information to all parts or individuals in the organization (Sawitri, Purwanti \& Setia, 2017). Furthermore, communication becomes the primary tool in organizational control, ensuring how the goals can be achieved according to the predetermined plan.

\section{Discussion}

In demonstrations with heterogeneous participants from various organizations, the challenges are enormous, one of which is how each organization controls internally to proceed according to the predetermined plan. The general chairman of the HMI Purwokerto Branch, Giovani Helmi Munif, revealed a narrative bias amid the action in the Omnibus Law demonstration on October 15, 2020. In a sense, when the situation becomes chaotic, another different narrative from the eight demands blows among the demonstration. The narrative was voiced by an unidentified demonstration participant from a particular organization. According to him, the narrative did not yield from a student organization.

The narrative bias is no longer aimed at getting the regent and the chairman of the 
regional representative council to change their position and sign the demands from the demonstration participants. Narrative bias becomes broader with national-scale targets. The narrative is associated with the change of the legitimate government in power. This narrative began to emerge when the demonstrations became increasingly damaging. The condition indicates an intruder group that has different interests. At this point, the communication role of the general chairman, action coordinator, and assistant action coordinator is crucial to control the internal organization, so they are not affected to be led in the interests of other parties and get carried away in a chaotic atmosphere. The success or failure of communication by most organizations is also determined by the quality of communication of organizational leaders. The organization leader is expected to have the ability to motivate, direct, influence, and communicate with all the members (Sanjiwani \& Wisadha, 2016).

Mature leadership and solid communication will be powerful tools in organizational control. A further description of how the organizational communication control strategy of the HMI Purwokerto Branch in the Omnibus Law demonstration will be analyzed through simple control, technical control, bureaucratic, and concertive control.

\section{Simple Control}

In his research, Edwards (1981) stated that simple control in organizations is related to communication built by organizational leaders to encourage subordinates to follow lawsuits. According to him, this type of control can fail if the organizational leadership does not accomplish and participate directly in supervising the members' activity (Meisenbach \& Jensen, 2017). In the Omnibus Law demonstration, the Purwokerto Branch of HMI succeeded in implementing simple control in harmony. This success was marked by the involvement of the general chairman of the HMI Purwokerto Branch to lead the demonstration directly. The general chairman ensured that the communication chain conducted well among its members so that when narrative bias and chaos transpired, HMI members remained solid on action purpose.

The communication chain of the HMI Purwokerto Branch in the Omnibus Law demonstration consists of three layers. This chain of communication that all members of the HMI Purwokerto Branch should understand and obey. The general chairman holds the first layer at the top chain of command and communication. Then, the second commando is held by a coordinator at the next level. The next layer of the third commando is the assistant action coordinator of three people. The five people (Chairman, Action Coordinator, and Assistant Action Coordinator) do not stand in the exact location but are scattered in predetermined locations.

The action scheme carried out by the Purwokerto Branch of HMI applies the "claw crab" model, specifically, a demonstration model in the letter $U$ shape with the target of the action being in the middle of the letter "U." The general chairman is in the front row by holding the primary communication tool as the narrative controller. Meanwhile, the assistant coordinator of the action consisted of three people spread to the right, left, and center of the crowd of active participants. The position of the action coordinator is in 
a more dynamic position, changing locations according to the needs of the participants.

The placement of assistant coordinators of action spread to the right, left, and center of the masses keeps the circle sterile; no outsiders can penetrate the circle. This arrangement is essential because unidentified persons or intruders need to be separated in a heterogeneous mass from the crowd. The assistant coordinator plays an essential role in keeping the area sterile and establishing communication with its members to be not separated from the circle. Each assistant action coordinator is responsible for controlling communication, supervising, maintaining, and ensuring that the number of members in their area does not decrease or increase.

The action coordinator moves dynamically as the outermost communication layer fully observes the mass movement. The action coordinator also observed the behavior of each member to keep it well controlled and not to get carried away by the heated atmosphere of the demonstration. In research conducted by Hasse (2012), demonstrations carried out primarily by students (almost always) ended in violence. The patterns and tendencies of violence that arise are relatively identical. Clashes with security forces are the 'primary choice' for students because they have substantial reasons. The security forces were assumed not to be pro-students because their actions were continuously monitored and blocked. In this condition, the action coordinator chosen by the general chairman should have a personal classification that has intellectual maturity and adequate emotional control. This arrangement is made so that the demonstration remains focused on the goal while still paying attention to members' safety.
Burris, B. H. (1989) explains three things that need to be emphasized in simple control: direct supervision, coercive authority, and time discipline. HMI Purwokerto Branch implements direct supervision by applying three layers of vertical communication lines. In a sense, all Purwokerto Branch of HMI members who took part in the demonstration only followed the instructions issued by the three layers of communication structure. This communication layer is tiered. The first layer has the highest authority to follow a mutual agreement before the demonstration is held. So, when members do not comply with the communication layer, the Chairperson, the action coordinator, and the assistant action coordinator will apply coercive authority.

Meanwhile, time discipline is defined as the compliance of organizational members to the agreed timeline. The implementation of the demonstration time has been arranged taking into account various things. When the implementation of the demonstration has exceeded the specified time, then the action is not in line with the Purwokerto branch of the HMI agenda anymore.

The discipline of timing is crucial in demonstrations. This matter was communicated in the discussion before the action. One of the goals of time discipline is to minimize the potential for intruders to take advantage of the demonstration. HMI Purwokerto Branch has predicted the estimated time spent for the demonstration. Likewise, when demands are not fulfilled and negotiations fail, the HMI Purwokerto Branch will take a stand to end the demonstration peacefully and harmoniously. The organization will further examine alternative solutions at different periods. 
Nevertheless, unfortunately, what occurred in the field was just the opposite. Towards the end of the allocated time limit, another group took advantage of the situation. When the regent and the chairman of the regional representative council did not comply with the demands, the demonstration suddenly became chaotic.

Under such conditions, the three layers of communication at the HMI Purwokerto Branch focus on the safety of members. Directing members to move at a predetermined endpoint, namely, the area of the Muhammadiyah Regional Leadership building, Banyumas Regency, Jl. Dr. Number 1, Purwokerto. The Chairperson, action coordinator, and assistant action coordinator always communicate to members so that they do not take unlawful actions during demonstrations. This appeal was conveyed from the beginning of the speech until the situation began to heat up and become chaotic. All members of the HMI Purwokerto branch managed to implement reasonable simple control. As a result, no victims were on the Purwokerto Branch of HMI, whether they were victims of police repression or were arrested by the police.

During the demonstration, the general chairman of the HMI Purwokerto Branch was separated from its members, but the communication control structure continued to work well and in stages. Communication control was continued by the action coordinator, who then ordered the assistant field coordinator to secure, calculate, and notice the members' physical condition. The communication structure determines the expected behavior of members. This structure is related to performance, roles, and determining the authority and reporting relationships of the entire series of roles contained in the organizational structure (Flamholtz, 1996). The control carried out by the Purwokerto Branch of HMI shows the existence of an excellent simple control role, applying a solid and intact communication structure. The implication is that the internal organization remains conducive even though the conditions in the field are already chaotic. When there was chaos, HMI chose to step down, not wanting to be mixed up with the unidentified masses who had other interests and could cause damage when damage has implications for harm. One of the references is the Quran Surah Al Baqarah verse 11, "Do not make mischief on earth" (Surah Al-Baqarah [2]: verse 11).

The solid organizational communication control reflects the quality of HMI as a professional and mature student organization. The HMI has declared its withdrawal from a demonstration when it indicates another agenda, chaos, or destruction. In a study conducted by Lia (2020), it was revealed that before the fall of the Orde Baru in 1998, the impact of the Trisakti tragedy spread to various regions in Indonesia, one of which was Palembang, South Sumatra. In action against the Trisakti tragedy, the 1998 Palembang Branch HMI, together with students from several universities in Palembang, took part in a demonstration, refusing to gamble, demanding a reduction in the price of essential commodities, cleaning up corruption, collusion, and nepotism in South Sumatra, as well as holding a dialogue on human rights and economic issues. This movement differed from that carried out by several masses who carried out the destruction during the action. The increasingly uncontrollable conditions made HMI Palembang Branch take the attitude 
of withdrawing from the demonstration area because certain groups had infiltrated the actions carried out by 12 universities to create divisions.

There is a clear difference between the spirit carried by HMI and other mass demonstrations. HMI exists as an organized and professional social, intellectual movement. When certain parties conveyed the narrative bias, HMI saw indications of other interests that wanted to tarnish the struggle for the action. HMI chose to resign but remained focused on the goal, explicitly encouraging organized social movements but prioritizing constitutional communication.

\section{Technical Control}

Technical control relates to certain limitations on using a set of tools. Technical control is also associated with specialized devices that positively contribute to organizational management. In the Omnibus Law demonstration in Purwokerto, a set of tools used by the HMI Purwokerto Branch was divided into two types, precisely, communication support and internal identification tools. Communication support is related to communication devices. Two types of devices are used; first, loudspeakers as a speech centre intended for all demonstration participants. Only the general chairman has control over the communication via loudspeakers. This device is in the forefront area, serving as fa speech control centre. The second device used is a mobile phone. All members use this device. Three sources of messages are the main priority for all members: news from the three layers of the communication structure: the chairperson, the action coordinator, and the assistant action coordinator.

HMI also pays special attention to the internal identification device used in the demonstration. In a demonstration involving many organizations, the HMI Purwokerto Branch as an extra-campus organization has a specific identity from the intra-campus organization. The intra-campus organization identify through the use of an alma mater coat, and for the Purwokerto Branch HMI, it can be identified through the mut (HMI cap) and Gordon. Both are HMI's distinctive identities. However, it is not used comprehensively for all demonstration members; those who use it are only the general chairman or administrators with a specific structural level.

Meanwhile, another identity device is used to identify the HMI demonstration members, specifically, a band on the left wrist. This device is a symbol of the organization's non-verbal communication that describes the similarity and cohesiveness of the internal identities of members of the organization during demonstrations. Internal identity is essential to maintain cohesiveness and strengthen group identity (Andhita, 2021).

Internal identification that distinguishes HMI Purwokerto Branch is also noticed in narration delivered during the oration. HMI Purwokerto Branch focuses on eight demands outlined in a written text intended for the regent and chairman of the regional representative council. There is consistency in the narrative delivered by the HMI Purwokerto Branch either orally or in writing through oration props such as banners and other written media. The narrative guides the action activity structured critically and logically. Overall, the communication tools used by the Purwokerto Branch of HMI in the Omnibus Law demonstration were able 
to characterize the internal identity that differentiated it from other organizations. Internal identification implies the common characteristics shared within the organization (Lee, 1971). Through exact identification, HMI Purwokerto Branch has established a distinctive identity. The specific identity strengthens the shared characteristics, attitudes, and goals to be achieved.

\section{Bureaucratic}

Bureaucratic relates to using organizational procedures and formal rules (Novianti, 2019). In the demonstration against the Omnibus Law, the HMI Purwokerto Branch has communicated with the local authorities regarding standard regulatory procedures. These rules include sending a written notification letter to the Banyumas Police by explaining the intent, purpose, location, route, time, the person in charge, number of participants and other important information. The HMI had also conducted a detailed study related to the procedure for delivering opinions in public before the demonstration. The existence of three layers of communication structure, the general chairman, the action coordinator and the assistant action coordinator consistently ensure that all members understand and comply with the boundaries of the rules.

Action coordinators and assistant action coordinators play a central role in establishing simultaneous communication with their members so that demonstrators' behaviour remains following procedures. When the demonstration conditions start to heat up, and there are indications that members are getting carried away or showing the potential for anarchy action, the action coordinator will immediately pull the members back and calm down. The assistant coordinator also does the same procedure, and they are responsible for the movement of members who are within the scope of their supervision area.

The action coordinator and the assistant action coordinator should always be reflective, maintain emotional stability for themselves and their members. They should be certain the demonstration member does not break the rules, such as throwing stones at the polices, cursing the polices with dirty words or damaging public facilities. This adherence to procedural rules has prevented members of the HMI Purwokerto Branch from dealing with the police. The act of holding a demonstration is a fundamental right, protected by the freedoms of expression, assembly and association. A democratic government should not restrain citizens' right to protest under any circumstances. However, when citizens routinely stage disturbing protests, some community actors do not comply with democratic rules. (Cornell \& Grimes, 2015). The HMI Purwokerto branch also applies this understanding; the demonstration against the Omnibus Law is a constitutional right protected by law. Still, in practice, all members must remain subject to existing regulations and avoid damage.

HMI had carried out internal communication regarding organizational procedures before starting the demonstration. The process starts from an internal review of the urgency of demonstration, narrative research and establishing internal communication with organizational networks. Internal communication is built with two groups: the internal organization and alumni network, the Alumni Corps of the Islamic Student Association (KAHMI). KAHMI and 
HMI are two organizations that have similar goals and spirits. Communication between the two organizations is harmonious and synergistic.

\section{Concertive Control}

Concertive control is related to interpersonal relationships and teamwork to understand reality and values (Novianti, 2019). HMI Purwokerto Branch emphasizes the importance of member compliance with the existing structural communication levels. This compliance does not develop quickly but is formed through the cadre process carried out previously. The communication, emotional, ideological, normative, and familial ties are identical and strongly formed through this process. This bond facilitates solid communication during demonstrations against the Omnibus Law. It is manageable for the chairperson, action coordinator, and assistant action coordinator to establish complete communication during demonstrations and when organizing demonstrations. The general chairman and his staff regularly communicate with all members. Discussions are held to discuss the tasks, build relationships between members of the organization and discuss situations that require change (Molen \& Hoogland, 2005). Simultaneous communication increasingly encourages building the trust and sincerity given by members to the values supported by the organization.

On the other hand, the internal scope of the HMI Purwokerto Branch is not only related to the active members who joined the demonstration. Two other internal spheres are involved: interpersonal relationships between the HMI Purwokerto Branch and the Executive Board (PB) of HMI and interpersonal relationships between HMI Purwokerto Branch and alumni, personal or organizational networks.

The interpersonal relationships built by HMI Purwokerto Branch with PB HMI are harmonious, communicative, accommodating and solutive. Meanwhile, the interpersonal relationship between the Purwokerto Branch of HMI and the alumni network is synergistic. The culture at HMI is excellent; the relationship between seniors and juniors is built in a dialogical and harmonious atmosphere. Before deciding to participate in the demonstration against the Omnibus Law, the HMI had communicated with its senior network, the Alumni Corps of the Islamic Student Association (KAHMI). Communication is intended to gain support and contribute directions, suggestions, and advice for the organization. The HMI alumni network is spread across various elements of society and has a spirit of kinship, caring, helping and loyalty to the organization. This mechanism is one of the communication controls in the organization so that the decisions taken have objectivity values from various points of view.

The alumni network that has communicated with the HMI of Purwokerto Branch regarding demonstrations against the Omnibus Law consists of several variants. First, communication with alumni networks that are active in legal aid institutions. These alumni will be ready to help HMI members if there are legal issues related to demonstrations against the Omnibus Law. Second, the alumni network in the police institution. This communication with alumni is intended to help members of HMI if they were involved in legal problems; they do not have to excessive repressive actions. Third, alumni 
in the national legislation of the Republic of Indonesia; fourth, alumni network in political parties; fifth, alumni network in executive institutions; sixth, alumni network who work in mass media; seventh, other alumni networks spread across various professions.

The HMI Purwokerto Branch believes that support from alumni is an essential part of organizational control. There is an emotional bond already established. This emotional bond comes from a sense of togetherness, enthusiasm, values and organizational culture that have been built for generations. The primary matter that cannot be denied is that the alumni network has a vital role for HMI Purwokerto Branch. "Each role plays a special part in the communication network" (Pace \& Faules, 2005).

Directly or indirectly, when a member has a problem, the alumni network will undoubtedly come down to help other HMI members. The Concertive control applied by HMI Purwokerto Branch in the demonstration against the Omnibus Law. HMI Purwokerto Branch is an integral part of the HMI alumni network. Those spread across various fields are an essential part of organizational control, ensuring that the implementation of actions can handle according to the goals setting and pushing the priority of members' safety in the field. This condition is in line with the statement of Mesch and Manor (1998), people who are more attached to the community tend to be more socially and politically involved, and communities with people who are more attached tend to work together to achieve common goals (De Mello, 2020).

Overall, the organizational communication control strategy carried out by the HMI of Purwokerto Branch in the demonstration against the Omnibus Law focused on emphasizing the simultaneous communication with various parties involved in the demonstration. The message conveyed focuses on the implementation of democratic values itself. Demonstrations need to be understood as an aspirational and implementation tool in a democratic system.

In the study of social movements, several protest events (demonstrations) are also considered capable of triggering certain transformations (Della Porta, 2018). However, the demonstration against the Omnibus Law conducted by HMI Purwokerto Branch remained focused on the eight demands that had been previously set. HMI Purwokerto Branch understands how to properly communicate aspirations without violating people's rights to public spaces and public facilities. The chaos during the protest against the Omnibus Law in Purwokerto was not as HMI Purwokerto desired. The chaos also did not come from the HMI organization. The leadership of this organization has carried out strict communication control to avoid members getting injured in demonstrations with violence, riots, vandalism and various other actions that can potentially break the law. This control is essential because HMI is a critical intellectual organization with a constitutional, objective and rational communication approach.

\section{Conclusion}

In a demonstration against the Omnibus Law on October 15, 2020, in Purwokerto, Central Java, the HMI Purwokerto Branch could properly control organizational communication. Communication control is characterized by the clarity of the message, which comprises three layers of 
communication structure as a whole, rounded and solid. The message is emphasized on building a climate of protest following the freedom of expression implementation in a democracy. Simple control, technical control, bureaucratic, and concertive control built by three layers of command succeeded in placing this organization not involved in the chaos during demonstrations. HMI Purwokerto Branch considers that the chaos, vandalism and various acts of violating the law in the demonstration are not characteristic of this organization. HMI Purwokerto Branch is a critical intellectual movement that uses a constitutional communication approach. This approach makes this organization more mature and professional in responding to various problems in the community's social life.

\section{Bibliography}

Andhita, P. R. (2021). Pendampingan Penulisan Opini Media Daring pada PC IMM Banyumas dengan Pendekatan Group Achievement. Warta LPM, 24(2), 230- 238.

Anugrah, Arbi. (2020). Bubarkan Demo Omnibus Law di Banyumas, Polisi Tembakkan Gas Air Mata. DetikNews, 15 Oktober, https://news.detik.com/ berita-jawa-tengah/d-5215435/ bubarkan-demo-omnibus-law-dibanyumas-polisi-tembakkan-gas-airmata. Diakses 26 Januari 2021.

Burris, B. H. (1989). Technocratic organization and control. Organization studies, 10(1), 1-22. doi:10.1177/017084068901000101.

Clegg, S. (1981). Organization and Control. Administrative Science Quarterly, 26(4),
545-562. doi:10.2307/2392339.

Cornell, A., \& Grimes, M. (2015). Institutions as Incentives for Civic Action: Bureaucratic Structures, Civil Society, and Disruptive Protests. The Journal of Politics, 77(3), 664-678. doi:10.1086/681058.

Della Porta, D. (2018). Protests as critical junctures: some reflections towards a momentous approach to social movements. Social Movement Studies, 1-20. doi:10.1080/14742837.2018.155 5458.

De Mello, L. (2020). Population ageing and local governments: Does engagement with the local community change over the lifecycle? Local Government Studies, 1-22. doi:10.1080/03003930.2020.180 2253.

Flamholtz, E. (1996). Effective organizational control: A framework, applications, and implications. European Management Journal, 14(6), 596-611. doi:10.1016/ s0263-2373(96)00056-4.

Hasse, J. (2012). Anarkisme Demonstrasi Mahasiswa: Studi Kasus Pada Universitas Islam Negeri Alauddin Makassar. Muhammadiyah University Yogyakarta.

Johnson, W. H. A. (2011). Managing university technology development using organizational control theory. Research Policy, 40(6), 842-852. https://doi. org/10.1016/j.respol.2011.04.001.

Kementerian Hukum dan Hak Asasi Manusia, Undang-undang Nomor 9 Tahun 1998 tentang Kebebasan Menyampaikan Pendapat di Muka Umum (Jakarta: Dirjen Perpu, 2000), pasal 1 ayat 2.

Lee, S. M. (1971). An Empirical Analysis of Organizational Identification. Academy 
of Management Journal, 14(2), 213-226. doi:10.5465/255308.

Liu, Li. Borman, Mark. \& Gao, Jun. (2014). Delivering complex engineering projects: Reexamining organizational control theory. International Journal of Project Management. 32 (5), 791-802. doi:10.1016/j.ijproman.2013.10.006.

Meisenbach, R.J. and Jensen, P.R. (2017). Bureaucratic Theory. In The International Encyclopedia of Organizational Communication (eds C.R. Scott, J.R. Barker, T. Kuhn, J. Keyton, P.K. Turner and L.K. Lewis)s. https:// doi.org/10.1002/9781118955567. wbieoc014.

Muqsith, Munadhil Abdul. (2020). UU Omnibus Law yang Kontroversial. Jurnal ADALAH, 4 (3), 109-115.

Novianti, Evi. (2019). Teori Komunikasi Umum dan Aplikasinya. Penerbit ANDI: Yogyakarta.

Pace, R. Wayne dan Don F. Faules. (2005). Komunikasi Organisasi, Strategi Meningkatkan Kinerja Perusahaan. Editor: Dedy Mulyana. PT. Remaja Rosdakarya. Bandung.

Piyapong Boossabong \& Pobsook Chamchong (2021) Public policy in the face of posttruth politics and the role of deliberation, Critical Policy Studies, 15:1, 107-124, DOI: 10.1080/19460171.2020.1724168.

Prabowo, Haris. (2020). Omnibus Law Ciptaker Bermasalah Sejak Jokowi Mengusulkannya ke DPR. Tirto.id, 9 Oktober, https://tirto.id/omnibus-lawciptaker-bermasalah-sejak-jokowimengusulkannya-ke-dpr-f5Gl. Diakses 26 Januari 2021.
Sanjiwani, D. M. P., \& Wisadha, I. G. S. (2016). Pengaruh Locus Of Control, Gaya Kepemimpinan dan Komitmen Organisasi pada Kinerja Auditor Kantor Akuntan Publik. E-Jurnal Akuntansi, 14(2), 920-947.

Santiana, Lia. (2020). gerakan organisasi kemahasiswaan himpunan mahasiswa islam (HMI) cabang palembang 1998 (Doctoral dissertation, UIN Raden Fatah Palembang).

Sawitri, D., Purwanti, W. P., \& Setia, K. A. (2017). Analisis Pengaruh Kepemimpinan, Komunikasi, dan Sistem Kontrol Terhadap Kinera Organisasi Melalui Perilaku Pelayanan. Jurnal Manajemen dan Bisnis Indonesia, 5(1), 62-77.

Schäfer, M. S., \& Fähnrich, B. (2020). Communicating science in organizational contexts: toward an "organizational turn" in science communication research. Journal of Communication Management.

Selvanathan, H. P., \& Lickel, B. (2018). Empowerment and threat in response to mass protest shape public support for a social movement and social change: $\mathrm{A}$ panel study in the context of the Bersih movement in Malaysia. European Journal of Social Psychology. 49 (2), 23-243. doi:10.1002/ejsp.2502.

Suara Muhammadiyah. (2020). Kombes Whisnu Caraka Saling Klarifikasi Kapolresta Banyumas dan UMP. Suara Muhammadiyah, 16 Oktober, 2020, https://www.suaramuhammadiyah. id/2020/10/16/saling-klarifikasikapolresta-banyumas-dan-ump. Diakses 26 Januari 2021.

Subianto, Prabowo.(2020). Demo Ditunggangi, 8 Petinggi KAMI Ditangkap Radar 
BanyumasRABU. Radarbanyumas,co. id, 14 Oktober, https://radarbanyumas. co.id/demo-ditunggangi-8-petinggikami-ditangkap. Diakses 26 Januari 2021.

Syahputra, I. (2017). Demokrasi virtual dan perang siber di media sosial: Perspektif Netizen Indonesia. Jurnal Aspikom, 3(3), 457-475.

Tumskiy, Stanislav, Provocation in Social Interaction: Precursors, Phenomenon, and Areas of Application (September 1, 2019). Available at SSRN: https://ssrn. com/abstract $=3502058$.

Wekke, Ismail S., and Sidratahta Mukhtar. 2019. 'Students' Movement and Political Participation: Research on the Association of Islamic Student in Indonesia." INA-Rxiv. February 4. doi:10.31227/osf.io/nqct3.

Van der Molen, H. T., \& GramsbergenHoogland, Y. (2005). Communication in organizations: Basic skills and conversation models. Taylor \& Francis e-Library, 2005. 